ROCZNIKI HUMANISTYCZNE

Tom LXIX, zeszyt $6-2021$

ZESZYT SPECJALNY

DOI: https://doi.org/10.18290/rh21696s-6

DANUTA KOWALSKA

\title{
OBRAZ ZARAZY W ŚWIETLE TRAKTATU MEDYCZNEGO PIOTRA UMIASTOWSKIEGO PT. NAUKA O MOROWYM POWIETRZU NA CZWORY KSIĘGI PRZEŁOŻONA (1591)
}

Epidemie chorób zakaźnych towarzyszą człowiekowi od najdawniejszych czasów, rzadko kiedy ograniczając swój zasięg do terytorium jednego państwa, powodując destabilizację życia, a poprzez wysoką śmiertelność negatywnie wpływając na losy całych społeczeństw ${ }^{1}$. Epidemie nękały również mieszkańców dawnej Polski. Naznaczone nimi było także całe XVI stulecie: kolejne fale morowego powietrza pojawiały się co kilka lat, pustosząc główne miasta Rzeczypospolitej. Niektóre z nich trwały długie lata, wyniszczając ludność całej Polski, jak choćby epidemia dżumy w latach 1587-1592 (Karpiński 69). Według wyliczeń historyków, w XVI wieku procent lat z epidemiami sięgał nawet 60 (Kracik 311, Giedroyć 48-52). Nie dziwi więc, że temat zarazy przewija się w wielu dawnych tekstach: pamiętnikach, listach, kazaniach, kronikach, okolicznościowych wierszowanych utworach literackich ${ }^{2}$ itp. Szczególnie cennym źródłem tego typu informacji są zwłaszcza zachowane traktaty medyczne i poradniki przeciwepidemiczne ${ }^{3}$.

Dr hab. DANUTA KowALSKA, prof. UŁ - pracownik Zakładu Historii Języka Polskiego UŁ; adres do korespondencji: Instytut Filologii Polskiej i Logopedii Uniwersytetu Łódzkiego ul. Pomorska 171/173, 90-236 Łódź; e-mail: danuta.kowalska@uni.lodz.pl; ORCID: https://orcid.org/0000-0002-5550-5650.

${ }^{1}$ Szacuje się, że podczas największej epidemii dżumy w Europie w latach 1348-1350, zwanej Czarną Śmiercią, zmarło 25 milionów ludzi, co stanowiło wówczas od jednej trzeciej do nawet połowy całej ówczesnej populacji (Kracik 16-17).

${ }^{2}$ Źródła literackie (kazania okolicznościowe, wierszowane dzieła dewocyjne, m.in. modlitwy i kancjonały, oraz świecka literatura piękna) wskazuje m.in. Piotr Borek.

${ }^{3}$ Problem zapobiegania epidemiom po raz pierwszy podjął Maciej z Miechowa w opublikowanej w 1508 roku w Krakowie książce pt. Contra saevam pestem regimen accurattissimum. O sposobach 
W niniejszym artykule przedmiotem zainteresowania czynimy tekst traktatu medycznego pt. Nauka o morowym powietrzu na czwory księgi przetożona, napisany przez Piotra Umiastowskiego z Klimont, $w$ filozofijej $i$ w lekarskiej nauce doktora, wydany w Krakowie w roku 1591, w drukarni Andrzeja Piotrkowczyka. Na ten obszerny, liczący 278 stron, utwór składają się - zgodnie $\mathrm{z}$ podaną $\mathrm{w}$ tytule dzieła zapowiedzią - cztery księgi, w których uczony medyk przedstawia kolejno: przyczyny powstawania morowego powietrza, zwiastuny zarazy, formy profilaktyki oraz objawy choroby i sposoby jej leczenia. Tekst ten zasługuje na uwagę z kilku powodów. Przede wszystkim nie był on dotychczas obiektem językoznawczych badań, nieliczne wzmianki na jego temat pojawiały się jedynie w opracowaniach literaturoznawczych (Kuran) oraz pracach z zakresu historii (Giedroyć) oraz dziejów medycyny (Gajewska). Nie ma go także wśród tekstów źródłowych Słownika polszczyzny XVI wieku, a więc zawarty w nim materiał językowy nie mógł być choćby punktem odniesienia dla historyków języka. Tekst ten nie był także uwzględniany w badaniach poświęconych początkom kształtowania się oraz ewolucji polskiego stylu naukowego (Biniewicz, Jankowiak, Siekierska, Kuryłowicz ${ }^{4}$. Materiał leksykalny zawarty w poradniku Piotra Umiastowskiego może więc stanowić cenne uzupełnienie wcześniejszych badań poświęconych kształtowaniu się

leczenia dżumy pisał także Stefan Falimirz w dziele $O$ ziołach i mocy ich (Kraków 1534). Z XVI wieku pochodzą także traktaty medyczne, pisane przez doktorów, m.in.: Ksią̇ki o zachowaniu zdrowia czlowieczego od zarazy morowego powietrza doktora Antoniego Schneebergera, z tacińskiego na polski język teraz nowo przez Jana Antoniusza przełożona, Kraków 1569; M. Ruffusa, Epitome opusculi, to jest gruntowna i dostateczna sprawa o jadowitej i zaraźliwej niemocy pestilencyjej albo morowego powietrza, Kraków 1588; Piotra Umiastowskiego, Nauka o morowym powietrzu na czwory księgi rozłożone, Kraków 1591. Z XVII wieku pochodzą kolejne traktaty poświęcone tej tematyce, m.in.: Marcina z Klecka, Obrona przeciw morowemu powietrzu doświadczona, 1605; Sebastiana Petrycego z Pilzna, Instrukcyjna abo nauka, jak się sprawować czasu moru... dla prostych napisana, krom diskursów, Kraków 1613, J. I. Petrycego, Praeservatio abo Ochrona powietrza morowego, Kraków 1622; Sebastiana Śleszkowskiego, O ustrzeżeniu się i leczeniu morowego powietrza, także goraczekjadowitych przymiotnych z petocyjami, nauka każdemu wiekowi, ptci i stanowi przysposobiona, tak z nauczonych i sławnych medyków, jako i z samego doświadczenia krótko zebrana, Kalisz 1623; Sebastiana Śleszkowskiego, Jasne dowody o doktorach żydowskich, 1623; M. J. Sokołowskiego, Bonae spei promontorium albo o morowym powietrzu nauka. $Z$ różnych autorów osobliwie niemieckich..., Kalisz 1679.

${ }^{4}$ Uwaga lingwistów w tym zakresie koncentrowała się przede wszystkim na najstarszych polskich podręcznikach: Algorytmie T. Kłosa, Geometrii S. Grzepskiego (Biniewicz: „Początki polskiego języka nauk ścisłych”, „Kształtowanie się polskiego języka”, „Początki polskiego stylu naukowego”) oraz poradnikach zielarskich, zwłaszcza traktacie O ziołach i mocy ich Stefana Falimirza (Jankowiak: „Terminologia medyczna”, „Nazwy chorób w polszczyźnie”, Stownictwo medyczne t. 1 i 2, „Z dziejów terminologii medycznej”, „Zapożyczenia”), traktacie Problemata Arystotelis. Gadki o składności człowieczych członków Andrzeja Glabera z Kobylina (Migdał), poradniku Piotra Krescencjusza (Kamper-Warejko) i in. 
polskiego języka nauk przyrodniczych. Ponadto utwór ten ze względu na tematykę skoncentrowaną na jednym rodzaju choroby oraz stosunkowo dużą objętość jest niezwykle wartościowy dla współczesnych badań historycznojęzykowych, związanych z językowym obrazem świata oraz sposobami konceptualizacji choroby w polszczyźnie. Traktat odsłania bowiem nie tylko ówczesny stan wiedzy na temat istoty i genezy chorób epidemicznych, ale także odzwierciedla utrwalone w języku potoczne rozumienie zarazy, związane ze stanem świadomości człowieka drugiej połowy XVI wieku.

W niniejszym artykule postaram się ukazać obraz dżumy nakreślony przez Piotra Umiastowskiego. W obrazie tym kryje się oczywiście dawny sposób postrzegania choroby, ukształtowany przez stan ówczesnej wiedzy medycznej. Rekonstrukcja obrazu choroby zmierzać więc będzie do odsłonięcia kryjących się w języku mechanizmów ludzkiego myślenia o chorobie. Język bowiem utrwala wzorce myślenia o zjawiskach, których człowiek doświadcza, lęk przed tym, czego człowiek nie potrafi zrozumieć i wyjaśnić (Marczewska, Ja cię zamawiam 7). W języku zakodowane są także różnego rodzaju kompleksy myślowe dotyczące choroby, warunkowane kulturowo i wynikające ze społecznej świadomości. W badaniach odwołuję się do definicji językowego obrazu świata (JOŚ), sformułowanej przez Jerzego Bartmińskiego (Bartmiński 103-120). Problematyka językowego obrazu choroby była przedmiotem zainteresowania lingwistów, jednak ich uwaga albo skupiała się na innych tekstach, powstałych w różnych okresach rozwoju polszczyzny (Migdał, Umińska-Tytoń), w tym także na źródłach etnograficznych (Marczewska), albo koncentrowała się na zabiegach językowych związanych z metaforyzacją pojęcia CHOROBA (Raszewska-Żurek, Chojnacka-Kuraś) i śledzeniu zmian semantycznych, jakie zachodziły w polszczyźnie w grupie leksemów związanych $\mathrm{z}$ tym pojęciem (Stec). Prowadzone w niniejszym szkicu analizy z jednej strony odsłaniają więc jednostkowy obraz choroby, utrwalony w dziele Piotra Umiastowskiego, z drugiej zaś mogą stanowić uzupełnienie wcześniejszych badań, poszerzając stan wiedzy na temat obrazu choroby w dawnej polszczyźnie.

W toku analiz omówię nazwy choroby, stosowane w dziele na określenie dżumy, w których zazwyczaj kryje się określone wartościowanie, jej cechy i atrybuty, objawy oraz przyczyny - wszystkie te zjawiska związane są bowiem z mówieniem o chorobie, stają się więc kluczem do rozumienia i wyjaśniania świata z perspektywy człowieka drugiej połowy XVI wieku. Zwrócę także uwagę na wybrane zabiegi językowe, kształtujące obraz choroby, zwłaszcza udział leksyki wartościującej oraz środki wpływające na obrazowość kształtowanej w tekście przestrzeni semantycznej. 
Przystępując do analizy, trzeba pamiętać, że ukazany w traktacie obraz dżumy został ukazany z perspektywy człowieka uczonego, doktora medycyny i filozofii, który kształcił się w Akademii Krakowskiej i w Bolonii, praktykował zaś na dworze książąt Czartoryskich. Umiastowski - wzorem innych autorów tego okresu - swoje obserwacje oparł na antycznych i średniowiecznych autorytetach, których kompletną listę dołączył do swego dzieła. Są wśród nich zarówno doktorzy, m.in.: Hipokrates, Galenus, Awicenna, jak i filozofowie: Platon, Arystoteles, a także poeci: Homer, Wergiliusz, Owidiusz. Powoływanie się na autorytety miało, jak można przypuszczać, przekonać odbiorców o medycznym doświadczeniu autora i dysponowaniu przezeń skutecznymi metodami leczenia, a więc był to zabieg podporządkowany sferze perswazji (Kuran 78). W przedmowie autora do czytelnika czytamy:

Tedy ja chcąc zarazy morowej, jadowitej i zdradliwej przyrodzenie i skutki tym jaśniej pokazać, nie jakim sposobem nowym, naśladując lacinników w dyskursie, Naukę o morowym powietrzu na czwory księgi rozdzieliłem i opisałem. Nie dla tego, abym miał jaką chlubę z swego niewielkiego dowcipu odnieść, lecz abym tym dowodniej o morowym powietrzu opisał. Gdyż teraźniejsze czasy to niosą za jakąś zamieszką, że nie tylko o przyrodnych rzeczach, ale ktore są nad rozum ludzki (choć prości ludzie) dwornie wywiadują się. (k. 39)

Adresatem poradnika był prosty i niewykształcony odbiorca, należało więc pisać o chorobie językiem zrozumiałym i obrazowym, i w taki sposób, by udzieliwszy praktycznych rad, przekonać do określonych działań. Niemożliwe więc było wyrwanie się z potocznych sposobów porządkowania pojęć i potocznej perspektywy interpretacyjnej. Trzeba było temat choroby „oswoić”, a w świecie zewnętrznym odnaleźć pewne i stałe punkty oparcia, by móc nad tym przykrym, wywołanym chorobą, doświadczeniem zapanować. Tym względem trzeba więc tłumaczyć fakt, że zdecydowana większość zawartego w dziele słownictwa medycznego stanowią nazwy rodzime, funkcjonujące w codziennym życiu, znane z potocznego doświadczenia człowieka niemającego medycznego wykształcenia. Odwoływanie się do istniejącej już tradycji mówienia o medycynie było zwyczajem stosowanym już we wcześniejszych utworach o tematyce medycznej ${ }^{5}$ (Jankowiak, Stownictwo medyczne 1:311). W tym miejscu warto zauważyć, że ilekroć Umiastowski wprowadza jakiś zapożyczony z łaciny bądź greki termin medyczny, zawsze towarzyszy mu szczegółowe wyjaśnienie, objaśniające etymologię obcego leksemu, najczęściej też zawierające określenia synonimiczne, np.:

\footnotetext{
${ }^{5}$ L. Jankowiak podaje, że w Zielniku Stefana Falimirza udział rodzimej leksyki medycznej wynosi 73,3\% (Jankowiak, Stownictwo medyczne 1:311).
} 
Wtory rodzaj pospolity albo najpospolitszy, ilekroć tegoż rodzaju choroby tułają się, ktore albo $\mathrm{w}$ jednym kraju, albo $\mathrm{w}$ wielu krainach najdują się. Jeśli $\mathrm{w}$ jednym kraju, zowią je z greckiego endemii, polskim językiem dziedziczna, ojczyste. (1v)

A dlaczegoż jest nazwany od łacinników carbo abo carbunculus, a po polsku wągl albo wąglik? Nie dla czego inszego, jedno dla swej materyjej zepsowanej, jadowitej morowej gorącej ognistej, pałającej, iż tak właśnie pali jako kiedy świeca albo wągl rozpalony, gdyby był do ciała przyłożony. (86v)

Tego rodzaju objaśnienia pełnią funkcję dydaktyczną, a dla współczesnego badacza są znakomitym materiałem badawczym.

\section{NAZWY CHOROBY I JEJ ATRYBUTY}

Użyte w tytule dzieła zestawienie morowe powietrze w XVI wieku używane było w odniesieniu do różnych chorób zakaźnych, o rozmaitych przyczynach i drogach rozprzestrzeniania się, najczęściej jednak mianem tym określano tzw. czarna śmierć, czyli dżumę, która od najdawniejszych czasów dziesiątkowała ludność świata. Potwierdza to SPXVI, w którym znajdujemy następującą definicję tego określenia: 'epidemia groźnej gorączkowej choroby zakaźnej, najczęściej tzw. morowej zarazy, czarnej śmierci (mors nigra), czyli dżumy'. Ogólną definicję morowego powietrza podaje w swym traktacie także Piotr Umiastowski, wskazując najważniejsze cechy wywoływanej przez nie choroby: łatwość rozprzestrzeniania się, a co za tym idzie - powszechność, zaraźliwość i śmiertelność: Powietrze morowe nic inszego nie jest, jedno choroba pospolita trapiaca, ktora po wielu krajow, krolestw, księstw szerzy się, śmiertelna i barzo zarażajaca. Tu po prostu powietrze rzeczono (3v), jeśli (choroby - D. K.) ludzie zarażaja, traca, gubia, zabijaja, zowia je morowym powietrzem (1v), Powietrze morowe jest choroba pospolita, abowiem żadne morowe powietrze nie jest bez zarazy (4r), choroba zaraźliwa to jest powietrze morowe (2r), każde powietrze morowe być zaraźliwe (3r), powietrze morowe to jest wiatr zarażajacy (11r), powietrze morowe wszystkich najwiętsza jest zaraza (3r). W badanym traktacie funkcjonują także inne określenia synonimiczne nazywające dżumę. Wielość określeń odnoszących się do tego samego desygnatu trzeba uznać jako przejaw poszukiwań takich środków językowego wyrazu, które w sposób najpełniejszy oddadzą istotne cechy schorzenia (Steczko 166). Dawniej klasyfikowano choroby na podstawie najbardziej charakterystycznych objawów, stąd wiele $\mathrm{z}$ wynotowanych określeń ma charakter językowo-kulturowej kreacji i obrazuje nie tylko funkcjonujące w powszechnym obiegu poglądy 
na temat pochodzenia choroby, ale także odsłania towarzyszącą jej postrzeganiu ocenę i sposób wartościowania. Wśród wynotowanych nominacji występują nazwy jednoelementowe: powietrze 'zaraza, epidemia' (SPXVI): Tu po prostu powietrze rzeczono $(3 \mathrm{v})$, co potrzeba przełożonym [...] czynić [...], niżeli się powietrze zacznie (k. 43), zaraza 'wszystko, co zaraża, choroba zarażająca, epidemia' (SWil), 'to, co zaraża, choroba zaraźliwa, nagminna, łożnica, pomór, epidemia' (SW) (k. 36, k. 39, k. 40, 2r, 12r, 12v, 16r, 20v, 21v, 22r), mor 'każda wielka epidemia gorączkowej choroby zakaźnej, w szczególności zaraza morowa, zwana też czarną śmiercią, dżumą, dziesiątkująca tysiące ludzi' (SPXVI): znaki moru (k. 32); dwuelementowe: choroba powietrzna (6v), choroba morowa (34r, 79r)/morowa choroba $(78 \mathrm{r}, 79 \mathrm{v})$, niemoc morowa $(33 \mathrm{v})$, zaraza morowa $(57,88,97,99,24 \mathrm{r}, 41 \mathrm{r})$, zaraza powietrza $(11 \mathrm{r})$; zaraza powietrzna $(15 \mathrm{v}) /$ powietrzna zaraza $(15 \mathrm{v})$, powietrze trapiace $(3 \mathrm{v})$ : Nazwane jest powietrze trapiace dla wielu krain od niego opanowania (3v), morowa plaga (k. 32), zaraza przerzutnia $(42 \mathrm{v})$, jak również zestawienia składające się z trzech członów: choroby powietrza morowego (k. 39), zaraza powietrza morowego ( $k$. 50, 18r, $24 \mathrm{r}$ )/zarazy morowego powietrza (45r), przyrzutne ('zaraźliwe, zakaźne' SPXVI) powietrze morowe (41r), plaga morowego powietrza (k. 32). Analiza nazw, ich etymologii, łączliwości wyrazowej wskazuje, że kryje się w nich określone wartościowanie, przede wszystkim zaś informacja o sposobie przenoszenia się choroby oraz o skutkach, jakie ona wywołuje. To choroba, która przychodziła znienacka, wraz z powietrzem, szybko i gwałtownie się rozprzestrzeniająca, masowo doprowadzająca do śmierci ${ }^{6}$. Świadectwem przekonania ówczesnych ludzi, że choroby zakaźne biorą się $\mathrm{z}$ powietrza są wynotowane nominacje $\mathrm{z}$ członem powietrze / powietrzny: powietrze morowe, powietrze, przyrzutne powietrze, powietrze trapiace, zaraza powietrza, zaraza powietrzna, choroby powietrza morowego, zaraza powietrza morowego, plaga morowego powietrza. Określenie zaraza bądź zestawienia z tym leksemem: zaraza morowa,

\footnotetext{
${ }^{6}$ Pokłosiem funkcjonowania dużej liczby synonimicznych określeń na nazwanie morowego powietrza jest wielość określeń nazywających osoby zakażone morem. Zazwyczaj kryje się w nich informacja o źródle choroby (powietrze) oraz jej zaraźliwości. W badanym traktacie wśród wyekscerpowanych nazw pojawiają się nominacje jednoelementowe: zapowietrzony $(32 \mathrm{v}, 50)$, zarażony (77) oraz wieloelementowe: czlowiek zapowietrzony (32r), zarażony powietrzem (95), powietrzem morowym zarażony (48)/morowym powietrzem zarażony (95), chory powietrzem morowym zarażony $(30 \mathrm{v})$, schorzaly na morowe powietrze (79r), rozchorzaly na morowe powietrze (52), morowym powietrzem zdjęty (33v). Pojawia się także zestawienie o charakterze tautologicznym zawierające aż dwa leksemy odsyłające do desygnatu powietrze: zapowietrzony morowym powietrzem (97). Na uwagę zasługuje także wynotowane określenie o metaforycznym zabarwieniu: jadem morowego powietrza zraniony $(35 \mathrm{v})$.
} 
zaraza powietrza, zaraza przerzutnia nawiązują z kolei do szybkiego, gwałtownego rozprzestrzeniania się choroby i są powiązane z czasownikiem zarazić, funkcjonującym w polszczyźnie od połowy XIV wieku ${ }^{7}$ Stownik staropolski notuje go w następujących znaczeniach: 'porazić, uderzyć; przenośnie: uderzyć, aby zniszczyć; dotknąć nieszczęściem (chorobą, plagą, śmiercią), zatruć, zepsuć, skazić'. Czasownik ten jest przedrostkowym derywatem utworzonym od czasownika razić, pochodzącego od prsł. *raziti 'ciąć, siec, zadawać ciosy, uderzać, ostro oddziaływać na zmysły lub umysł' (SEBor 511). Tu warto dodać, że interesującą definicję zarazy zawarł w dziele sam Umiastowski: zaraza nic inszego nie jest, jedno użyczenie choroby od jednego człowieka do drugiego, albo od jednej rzeczy do drugiej podobnej we wszystkim sobie (14v). $\mathrm{Z}$ kolei rzeczownik mór oraz zestawienia z przymiotnikiem morowy: choroba morowa, niemoc morowa, zaraza morowa, plaga morowa konotują informację o masowym umieraniu wywołanym groźną chorobą zakaźną. Leksem mor pochodzi od prsł. *morb 'pomór, zaraza, epidemia' i jest derywatem wstecznym od *moriti 'morzyć, uśmiercać', *merti 'umierać' (por. morzyć 'zadawać komuś śmierć, męczyć, dręczyć powolnie').

Wymienionym nominacjom, funkcjonującym w dziele jako synonimy, bardzo często towarzyszą dodatkowe określenia przymiotnikowe, najczęściej w funkcji przydawki, uwypuklające jedną bądź kilka charakterystycznych właściwości choroby. Są to przeważnie leksemy o negatywnych konotacjach, silnie oddziałujące na emocje odbiorcy. W tej funkcji najczęściej wykorzystywane są leksemy srogi 'wielki, budzący strach' (Sstp), konotujący lęk towarzyszący epidemii: sroga plaga morowego powietrza (k.19); srogie powietrze $(6 \mathrm{v}, 13 \mathrm{v}, 20 \mathrm{r}$, 25r), sroga zaraza (93r), wielki: czasu powietrza morowego wielkiego (17v), wielkie morowe powietrze roku Pańskiego 1528 (13v), straszliwy: morowa plaga straszliwa (k.32). Wartościujące przymiotniki oraz rzadziej przysłówki podkreślają także gwałtowność i szybkość rozprzestrzeniania się zarazy, jej okrucieństwo, przejawiające się w śmiertelnym przebiegu choroby oraz podstępnym, zdradliwym działaniu: rzecz jest gwaltowna powietrze morowe (k. 34), wielki jad morowy gwaltowny (79r), morowe powietrze jadowite (45r), zaraza morowa jadowita i zdradliwa (k.31), jad okrutny morowego powietrza (34v), jad okrutny morowy (85r), jad morowy chytry (44r), chytre powietrze (34r), jest (choroba morowa) prędko ludzie mordujaca i chytro zabijajaca (34r), morowe powietrze jest barzo zdradliwe (31r), powietrze morowe śmiertelne (63v). Nierzadko spotykamy szeregowe zestawienia przymiotnikowych określeń o negatywnych

\footnotetext{
${ }^{7}$ Losy leksemów zaraza, zarazić (się), zarażać (się) w polszczyźnie szczegółowo scharakteryzowała w ostatnim czasie Agnieszka Piela (Piela 98-104).
} 
konotacjach, które w jeszcze większym stopniu oddziałują na emocje odbiorcy. Kumulacja określeń stawała się dodatkowym środkiem wartościującym, służącym hiperbolizacji i wzmocnieniu ekspresywności wypowiedzi: wielkie a srogie powietrze $(20 \mathrm{v})$, niemoc morowa potężna i wielka $(33 \mathrm{v})$, powietrze morowe jadowite $i$ zabijajace jest $(75 \mathrm{v})$, Srogie byty $i$ wielkie insze morowe powietrza (25r), Wtedy morowe powietrza byly srogie, wielkie i znaczne (13v); choroby wielkie, zte, jadowite $(79 \mathrm{v})$, wielki i srogi, prędko i okrutnie zabijający jad morowy jest (102r-v). Takie nagromadzenie leksemów ma na celu, jak można przypuszczać, spotęgowanie drastycznego i gwałtownego przebiegu choroby, która w sposób okrutny i prędki może pozbawić życia. Podobny efekt wywołuje kumulacja synonimicznych form czasownikowych z pola semantycznego śmierci: A jeśli (choroby) ludzie zarażają, traca, gubia, zabijaja zowia je morowym powietrzem (1v). Godny uwagi jest fakt, że takie nagromadzenie pojawia się w zdaniu, które przybiera formę definicji pojęcia. Niektóre określenia towarzyszące nazwie choroby to stopniowalne przymiotniki parametryczne, które służą ukazaniu wielkości morowego powietrza (mierzonej wielkością objętego przez nie obszaru, czasem trwania epidemii $\mathrm{i} /$ lub liczbą spowodowanych przez nie zgonów). I tak powietrze morowe może być: maluczkie (13v), mniejsze $(9 \mathrm{v})$, śrzednie (14r), wielkie $(9 \mathrm{v}, 13 \mathrm{v})$, tęższe, czasem lżejsze, czasem mierniejsze $(12 \mathrm{v})$, znaczne i barzo wielkie $(12 \mathrm{v})$. Oto kilka wybranych przykładów: jeśli by przez cały rok trwało, na ten czas bytoby wielkie powietrze morowe, a jeśli by trwato tylko przez część roku, mniejsze by powietrze byto (9v), O znakach, ktore niniejsze morowe powietrze okazuja (30v), Wielkie też byto morowe powietrze roku Pańskiego 1528, ktorego czasu jako zacni kronikarze pisza, trzecia część ludzi na świecie była umarła. Wtedy morowe powietrza byly srogie, wielkie i znaczne (13v), w naszym kraju śrzednie powietrza morowe: to jest ani tęgie, ani lekkie, tylko śrzednie (14r). Niekiedy Umiastowski sięga po formy superlatywne przymiotników, chcąc ukazać maksymalne natężenie cechy nazywanej przez przymiotnik, a tym samym zintensyfikować znaczenie rzeczownika, którego jest on określeniem: niektorych ludzi zaraz morowa się chwyci jako jaka najsroższa trucizna serca $(17 \mathrm{v})$, A to ze wszystkich najwiętsza i najśmiertelniejsza zaraza jest, ktora ludzie bez żadnego znaku zwirzchniego bywaja zabijani (17v-18r), w najwiętszym $i$ w nasroższym powietrzu niektorzy podczas byli morowym powietrzem zarażeni $z$ samego miedzy domy pojźrzenia (21r), powietrze morowe nie jest watpliwa rzecz, że jest choroba najprędsza $i$ do zamordowania najsroższa (82v), powietrze morowe miedzy inszemi chorobami zaraźliwemi nad insze najwięcej jest zaraźliwsze (4r). 
Choroba, zwana morowym powietrzem, jest przez Umiastowskiego także metaforyzowana. Jest to powszechnie spotykany zabieg, gdyż w świadomości ludowej każda choroba zakaźna zazwyczaj istniała konkretnie i materialnie, pojawiając się w wielu postaciach i kształtach (Marczewska, Wyobrażenia choroby 87). Myślenie o chorobie jako o żywej istocie odzwierciedla właściwość ludzkiego postrzegania zjawisk abstrakcyjnych i silne dążenie ich konkretyzacji, co jest mechanizmem obronnym, zmierzającym do oswojenia własnego strachu (Marczewska, „Wyobrażenia choroby” 92). Z zabiegiem animizacji schorzenia spotykamy się już dwukrotnie w przedmowie autora do czytelnika, w której opisywana choroba ukazana jest jako sroga, rogata bestyja: Przeto abym tak sroga rogata bestyja, ktora nie jednego ostremi rogami swemi z światłości tego świata mizernego prędko straca, na sztuki wszytkie tym pilniej rozebrat; Aby się ta bestyja okrutna nie zwracała, co by przełożeni mieli czynić? (k. 31), od tej bestyjej okrutnej nieopatrznie zraniony jakoby się miat leczyć i ratować (k. 32-33). Podobny obraz odnajdujemy w Ksiegach trzecich traktatu: wielki strach a bojaźń ludzie była zdjęta, że ta bestyja okrutna nie mogła być pohamowana $(36 \mathrm{v})$.

$\mathrm{Na}$ kartach analizowanego dzieła kryje się także inny powszechny w dawnych czasach metaforyczny obraz choroby jako miecza/bicza Bożego, będący odzwierciedleniem przekonania, że zaraza jest karą za grzechy, którą Bóg zsyła na ludzi (Karpiński 33-35): o tym biczu Bożym srogim morowego powietrza nauke umyślitem pisać (A1), Że byto też to powietrze barzo zaraźliwe a jadowite po wielkiej porażce od miecza Bożego, ktory daleko i szeroko zasięgat (4v). Z podobnym obrazem spotykamy się w dołączonej do traktatu wierszowanej przedmowie do czytelnika, której autorem jest Petrus Kościński, co tylko potwierdza opinię o powszechności tego typu myślenia:

Coć bowiem po klejnotach, po skarbach, nieboże?

Gdy cię leda choroba snadnie pożyć może?

Zwłaszcza gdy Pan Bog ześle bicz srogi morowy,

Trudno się ma wybiegać tam wiera i zdrowy. (k. 32)

O świadomym zabiegu personifikacji choroby świadczą także wynotowane charakterystyczne połączenia wyrazowe z czasownikami nazywającymi czynność chodzenia, przemieszczania się, np.: Roku drugiego, to jest 1483, pożarem (srogie powietrze) do Wielkiej Polski, do Mazowsza poszło, zmocniło się, roszyrzyto się i po inszych przylegtych państwach wielka liczbę ludzi nieopatrznych pozabijato (6v), z stron poludniowych na zachod powietrze morowe idzie (41r), pręciuchno swoj bieg odprawuje i z niebeśpiecznościa bez pochyby 
prędko idzie, iż rychto zabija (82v), żagiew jadu odeszalaby $(79 \mathrm{v})$, choroby tutaja się w jednym kraju albo w wielu krajach (1r), choroby tutaja się, ktore albo $w$ jednym kraju albo $w$ wielu krainach najduja się (1v), rożne i rozmaite btakaja się zarazy, ktore jako tym albo onym przyjazne albo nieprzyjazne $(20 \mathrm{v})$, się ta choroba kotace $(32 \mathrm{v})$. W części połączeń wyrazowych odnoszących się do zarazy pojawia się leksyka wojenna, konotująca obraz choroby jako podstępnego, przebiegłego wroga, który przychodzi z zewnątrz i opanowuje całe miasta i kraje, raniąc i masowo mordując ludzi: powietrze morowe miasta i miasteczka zawsze więcej niżeli wsi wojuje (23r), powietrze morowe [...] do samego serca się wkrada (11r), powietrze morowe jeszcze srożej i szerzej panujace (4r), się ich powietrze chwycilo (95), powietrze morowe zwykło panować i moc swoje więtsza brać (37v), powietrze morowe okrutnie panuje (42r), morowe powietrze okrutnie poczyna panować (42v), choroby panuja (56), niektorych ludzi zaraz morowa się chwyci jako jaka najsroższa trucizna serca $(17 \mathrm{v})$, rychlej sie morowe powietrze chwyta (ciał) (80r), sie ich powietrze chwycilo (21r), zaraza morowa wielkie mnostwo ludzi pobita a pogromita (22r), pilniej się mogli strzedz, żeby tym jadem okrutnym morowego powietrza nie byli zranieni $(34 \mathrm{v})$, zaraza wiele zlych rzeczy może nabroić (22r), choroby barzo prędko mordujace $(83 \mathrm{v})$, ludzie powietrzem pomordowane $(24 \mathrm{v})$, morowe powietrze (...) napierwej się serca chwyta i serce okrutnie trapiac człowieka prędko zabija (31r), niektorych ludzi zaraz morowa się chwyci jako jaka najsroższa trucizna serca i nim się pokaża jakie znaki na wirzchu, natychmiast umieraja, jako się to trafia czasu powietrza morowego wielkiego, chodzac, jadac, siedzac, $i$ dalej $(17 \mathrm{v})$, powietrze morowe (...) prędko idzie, iż rychło zabija (82v), (choroba) wielka część ludzi stracita (3v), wielka liczbę ludzi nieopatrznych pozabijalo (6v), swa srogościa jadowita (powietrze) srodze ludzie morodowato i zabijalo (7r), ktorych śmierć zdradliwie zdtawila (34r), chytrym powietrzem gina (34r), Awicenna te chorobe chytra zaleca, że jest prędko ludzie mordujaca i chytro zabijająca $i$ dla tegoż z pomocnikami swemi srogiemi a okrutnemi, to jest z inszemi przypadkami przychodzi (34r), dla jej (choroby - D. K.) chytrości nie bywa poznana, a tak zdradliwa, że ani puls, ani uryna nie odmieniaja się wielka odmiana, a wszakże ona poczekawszy nieco potym schorzatego prędko i nagle zabija (34r). Wynotowane związki wyrazowe poświadczają charakterystyczne dla dawnych wieków i wciąż żywe w kulturze ludowej myślenie o chorobie jako niechcianym, groźnym, budzącym lęk przybyszu. Jak zauważa Marzena Marczewska, zjawisko uczłowieczania choroby jest głęboko zakorzenione w potocznym, ludowym myśleniu i wynikać mogło między innymi z przekonania, że na uczłowieczoną, a więc „oswojoną” 
chorobę można wpływać tak, jak się wpływa na innego człowieka (Ja cię zamawiam 171). Taka postawa człowieka wobec tej groźnej i szybko rozprzestrzeniającej się choroby znalazła odbicie w wyekscerpowanych połączeniach wyrazowych: zarazy trzeba się strzec, trzeba ją różnymi sposobami odganiać, odpędzać, wypędzać, wyrzucać, a nawet wniwecz obrócić: O strzeżeniu się morowego powietrza (39r), lekarstwa morowe powietrze odganiające (61r), jeśli jad morowy z ciała ludzkiego tym prędzej ma być wypędzony albo wyrzucony $(79 \mathrm{v})$, zaraze wniwecz obrócić (P44). Jednak najlepszym sposobem ratunku jest, zdaniem medyka, jak najszybsza ucieczka: uciekaj prędko, daleko, zeby cię on wiatr skażony a zepsowany nie dosiagt (45v). Według autora traktatu, temu lekarstwu, czyli ucieczce, nie jest żadne na świecie jemu rowne (45v).

\section{SYMPTOMY CHOROBY}

Stosunkowo dużo miejsca w swoim trakcie poświęca Umiastowski opisowi objawów choroby. Są one dość szczegółowe, a przede wszystkim obfitują w wartościujące słownictwo i porównania, których celem jest jak najdokładniejszy opis. Mają one nienaukowy charakter, wynikają z potocznego poznania, uwzględniają przede wszystkim cechy zewnętrzne schorzenia, które były wyraziste i łatwe do wychwycenia, a więc dostępne potocznemu doświadczeniu. Rejestr charakterystycznych objawów jest bardzo bogaty i różnorodny, pozwala mieć więc również wgląd w proces kształtowania się słownictwa medycznego w szesnastowiecznej polszczyźnie. Zgromadzony materiał pozwala wnioskować, że medyk rozróżniał podstawowe postacie dżumy: dymieniczną, płucną i posoczniczą. Do najczęstszych objawów choroby obok goraczki morowej (31r, $73 \mathrm{v}, 84 \mathrm{r}$ ) oraz febry morowej $(36 \mathrm{r}, 36 \mathrm{v}, 42 \mathrm{v})$ zaliczał przede wszystkim: bolenie głowy (32v), gwaltowne pragnienie, suchość języka i ścierniatości jego (31v), robienie piersiami barzo i wielkie tchnienie $(32 \mathrm{v})$, ciasność piersi (33v), puls niewielki a prędki (33r), smrodliwe tchnienie (32r), potem smrodliwym potnienie (32r), utracenie apetytu (33r), brzydliwość $(32 \mathrm{v})$, mdlość ustawiczna $(30 \mathrm{v}, 31 \mathrm{r})$, wracanie $(32 \mathrm{v}, 82 \mathrm{v})$, womity okrutne $(30 \mathrm{v})$, upadnienie sity (33r), omdlewanie (33r), odchodzenie od rozumu (30v, 82v), uryny mętne (82v) i sine (32r), puchliny (33v), niespanie (33r), kaszel dla obrażenia pluc od wiatru $\boldsymbol{i}$ wilgości zlych (33r). Dużo miejsca poświęcił zwłaszcza dymienicznej postaci dżumy, której charakterystycznym i bardzo nieprzyjemnym objawem były rozmaite bolesne wykwity na ciele. Medyk wymienia m.in.: makuty 'plama na ciele, objaw choroby skóry' (SPXVI) (92v, 94v)/makuty 
morowe (k. 45, k. 46, 92v, 96r)/makuły morowe zarażające (k.46); karbunkulus 'ropne zapalenie skóry, bardzo bolesny rodzaj owrzodzeń' (SPXVI) (86r)/karbunkut (87r, 87v)/karbunkulus morowy (86r)/karbunkut morowy (k. $45,83 \mathrm{v}, 87 \mathrm{r}) /$ wrzod karbunkut $(87 \mathrm{r}) /$ wagl $(86 \mathrm{v}) /$ waglik $(86 \mathrm{v})$, wrzody $(81 \mathrm{v}) /$ wrzody morowe $(82 \mathrm{v}) /$ dymienice morowe $(82 \mathrm{r}, 82 \mathrm{v})$ 'nabrzmienie węzłów chłonnych (najczęściej w pachwinach); też wrzód' (SPXVI)/dymienice albo bolączki $(81 \mathrm{v}) /$ bolaczki morowe $(82 \mathrm{v})$, krosty 'wyprysk skórny, też wewnętrzny; choroba objawiająca się wypryskami jak ospa, świerzb itp.' (SPXVI) (89r), ospice 'wypryski na skórze, wysypka, pryszcze; tez różne choroby, które się wypryskiem objawiają, np. osa, syfilis' (SPXVI) (k. 45, 89r)/ospice ropiste (89r). W opisie wyglądu skórnych objawów choroby niezbędnym środkiem wyrazu stawało się porównanie, które jako dwuczłonowa konstrukcja semantyczno-składniowa pozwalało na wprowadzanie nawet rozbudowanych obrazów, dając duże możliwości ukonkretnienia obrazu, celowego kształtowania pola konotacji asocjacyjnych i sięgania po skojarzenia bliskie odbiorcy, odwołujące się do jego (niekiedy bolesnych) doświadczeń i wiedzy. Wynotowane z tekstu traktatu konstrukcje porównawcze opierały się na relacji podobieństwa między porównywanymi obiektami, a więc umożliwiały doprecyzowanie kształtu, wielkości bądź natężenia jakiejś cechy. I tak medyk pisząc o makułach, czyli 'plamach na ciele', które są jednym z pierwszych objawów dymienicznej postaci dżumy, zauważa, że mogą one być różnej wielkości: niektore (makuły - D. K.) sq mate jakoby pokqsanie płech, niektore sq więtsze jako grosz albo czerwony zloty, niektore sq najwiętsze, iż jedna makula wszystek grzbiet osiada (94r). $\mathrm{Z}$ kolei charakteryzując swędzenie jako jeden z objawów ospic, odwołuje się do bolesnych doświadczeń odbiorcy związanych z kłuciem szpilkami: świerzbienie nozdrzy i uszu, wszystko ciało jakoby szpilkami po wierzchu ktot (89v). Doznania związane z odczuwaniem bólu przywołane zostały również w opisie wrzodu, zwanego waglikiem albo karbunkulusem morowym: tak pali jako kiedy świeca albo wagl rozpalony, gdyby byt do ciala przylożony (86v). Warto zauważyć, że ostatnia z cytowanych konstrukcji porównawczych jest także zręcznym narzędziem służącym wyjaśnieniu etymologii użytej nazwy wagl albo waglik. Podobny zabieg stosuje Umiastowski objaśniając znaczenie terminu karbunkulus: jako kamień karbunkulus miedzy kamińmi drogiemi jest znaczny, tak też wrzod morowy, ktory zowia karbunkulus miedzy inszymi morowymi wrzodami i barwa i boleniem $\boldsymbol{i}$ wielkim utrapieniem jest znaczniejszy (86r-v). Warto zaznaczyć, że wynotowane komparacje cechuje wyraźne emocjonalne zabarwienie, pełnią więc one w tekście (obok funkcji poznawczej i deskryp- 
cyjnej) także funkcję ekspresyjną, charakterystyczną bardziej dla tekstów artystycznych niż naukowych (Siekierska, $Z$ dziejów 226). Częstym środkiem oddziałującym na sferę emocjonalną odbiorcy, wykorzystywanym w opisywaniu objawów choroby, jest także sięganie po wartościującą leksykę. Widoczna jest ciekawa paralela w jej stosowaniu: Umiastowski zalicza morowe powietrze do tzw. chorób wielkich (4v), a więc także spowodowane nią objawy charakteryzowane są również jako wielkie i o wysokim natężeniu danej cechy: wiatr barzo pałajacy, ktory gdzie barzo pali, krew zapala i z wielkiego zapalenia bywaja wielkie zepsowania, a po wielkim zepsowaniu i zgniłości na ciele makuły się pokazuja (92v), kiedy jest wielkie zepsowanie a wielki zakat $w$ człowiecze, wielkie i srogie przypadki bywaja nań, to jest rozpalenie wielkie, glowy srogie bolenie, kaszel ciężki, womity okrutne, odchodzenie od rozumu częste, mdłość ustawiczna i insze (30v), bolenie wielkie głowy i grzbieta (89v), ktorzy ludzie zapowietrzeni sq, robia piersiami barzo i wielkie tchnienie maja, dla wielkiego ognia około serca i dla wielkości pary (32v), wielkim jadem morowym gwattownym (79r), byt jad wielki w onym człowieku, ktoremu mizernemu, utrapionemu natychmiast znaki czarne morowe pokazaty się i jak sie pokazaly trzeciego dnia po tym umart (80r). Wartościujące przymiotniki bądź imiesłowy przymiotnikowe stają się nieodzownym elementem opisu. Symptomy choroby określane są jako: srogie: bolaczki srogie (4v), głowy srogie bolenie (30v), okrutne: goraczki okrutne, womity okrutne, (30v), niebeśpieczne: karbunkut niebeśpieczny (87v), ciężkie: kaszel ciężki (30v), śmiertelne: bolaczka morowa śmiertelna (82v), mordujące: jad mordujacy (31r), zte: wilgości złe (33r, 75v), nieprzyjazne: jad morowy tak barzo jest przyrodzeniu nieprzyjazny (81v). Bardzo często pojawiają się w szeregowych zestawieniach, także w funkcji synonimicznej, co sprzyja intensyfikacji odczuć i hiperbolizacji: wrzod pałający, bolejacy, śmierdzacy i zarażający jest (87r), ciało schorzate, gorace i pałajace (16r), karbunkut jadowity i niebeśpieczny $(87 \mathrm{v})$, złe i jadowite wilgości (33v), materyja jadowita mordujaca a zabijajaca (75r). Nierzadko stają się także elementem zestawienia z nazwą jednostki chorobowej: ospy albo ospice śmiertelne (4v), karbunkulusze ogromne (4v), karbunkut morowy śmiertelny $(87 \mathrm{r})$, wielkie zapalenie $(92 \mathrm{v})$, rozpalenie wielkie $(30 \mathrm{v})$, wielki zakat $(30 \mathrm{v})$, bolenie wielkie glowy $(89 \mathrm{v})$. 


\section{PRZYCZYNY CHOROBY}

Piotr Umiastowski w swym traktacie niezwykle drobiazgowo i przystępnie, zgodnie z panującym stanem wiedzy medycznej i utrwalonymi w zbiorowej świadomości przekonaniami, wyjaśnia mechanizm zarażania się morowym powietrzem: zaraza nic inszego nie jest, jedno użyczenie choroby od jednego człowieka do drugiego. [...] a to użyczanie jest niektore ruszanie, badź czujne, bądź nieczujne (14v), bowiem gdy jeden bywa zarażony, drugi się też od niego zaraża (2r). Zarażenie dokonuje się oczywiście drogą powietrzną: $z$ wiatru zarażonego powietrze sie szerzy (20r), Śrzodek przez ktory bywa zaraza nie jest inszy jedno powietrze, ktore powietrze jako przyjmuje świattość, farbę, wonność, dym i w drugie ciała wpuszcza $(17 \mathrm{r}-17 \mathrm{v})$, powietrzem najblizsszy bywaja zarażeni, gdyż przez tchnienie zarażenie bywa (15v), zarażeni powietrzem morowym ustawicznie pary zaraźliwe powietrzem morowym z siebie wypuszczaja i jemi tchna $(22 \mathrm{v})$, do ich ciat ustawicznie duchy zaraźliwe bywaja puszczane, te wszystkie po wiatru rozpuszczone tacniuchno i pręciuchno $w$ drugie ciala wchodza i one zarażaja (22v). Takie powietrze jest określane jako: wiatr skażony (k.40), wiatr zarażajacy (3r), wiatr zepsowany $(7 \mathrm{v}, 23 \mathrm{r}, 23 \mathrm{v})$, zarażony wiatr $(24 \mathrm{v})$, para zaraźliwa $(8 \mathrm{r}, 22 \mathrm{v})$; para psująca i zarażająca (5r), powietrze zarażone $(21 \mathrm{v})$. Jako źródło tych zabójczych dla człowieka par medyk wskazuje osobę zarażoną: $z$ towarzyszenia albo bywania z zapowietrzonemi, świeży $i$ zdrowi się zarażaja, [...] nie iż by zarażeni będąc zarażali, ale iż wszyścy, ktorzy się zarażaja pospolitego wiatru używaja (2v). Dlatego radzi unikać przybyszów z innych krain: się to przydawa w wielkim, a w srogim powietrzu, $i z$ częstokroć zdrowi ludzie z zapowietrzonych krain, odjechawszy do zdrowych, zarażaja zdrowe i one krainy, do ktorych przyjeżḋaja, dlatego iż sami $w$ sobie majac morowe powietrze jako $w$ żagwi ogień insze ludzie zarażaja $i$ wiatr, a z wiatru zarażonego powietrze się szerzy (20r). Szczegółowo opisuje różne ogniska choroby, posługując się przy tym zręcznym, obrazowym terminem żagiew choroby ${ }^{8}$ lub żagiew powietrza morowego (45r), który precyzyjnie definiuje: Żagiew choroby nazwana jest ciało ono, ktore od zarażonego ciała zaraze albo truciznę przyjmuje i po tym drugiemu użycza (16r). Piotr Umiastowski zauważa, że zarazić można się także od rzeczy: żagiew, to jest ktorakolwiek rzecz, ktora by w sobie mogła morowe powietrze zachować, przyczyne powietrza morowego mogłaby mieć do drugiej żagwie albo rzeczy, $i$ żagiew do drugiej rzeczy zarażenia (18v). Jednak nie wszystkie przedmioty mogły być źródłem zarazy: zarażały przede wszystkim dziurkowate i miękkie, [...]

\footnotetext{
${ }^{8}$ Określenie to nie występuje w Zielniku Falimirza.
} 
ani nazbyt zimne, ani nazbyt gorące (16r). Unikać więc należało rzeczy sukiennych, lnianych, futernych wszelakich zwierzat [...] i drzew, ktore sq lekkie $i$ dziurkowate (16v). Medyk zauważa, że przyczyny powietrza morowego bywają dwojakie, oprócz zewnętrznych - także wewnętrzne, do których zaliczał: goracość nad przyrodzenie, materię zepsowana, gwattowna i wilgość albo parę psujaca i zarażajaca (5r). Ciała osób, które zawierają dużą ilość złych wilgotności, maja zakat do prędkiego zachwycenia powietrza morowego $(67 \mathrm{v})$, są więc najbardziej podatne na chorobę:

Abowiem ciała, ktore pełne są wilgości i ktorych zbytki nie bywają trawione jako przystoi, tym więcej przez prożnowanie i uspokojenie krzewią się i odmieniają się $\mathrm{z}$ onego zakału $\mathrm{w}$ powietrzną skazę. A tę miedzy inszemi zarazami wnętrzną zarazą dobrowolną może nazwać ludzi zarażonych początkiem powietrza. Bo jako sadzawka, ktora wody żywej a ciekącej w sobie nie ma, wśmierdzi się, a wśmierdziawszy się, ryby w niej i inne bestyje żywiące od onej zarazy zdychają, tak też i ludzie, mając w sobie pełność i zakał, onym członki swe martwią i umarzają, a ludzie od onychże samych zakażonych zarażają się i koniec żywota swego z nieopatrzności swej miewają. (56v)

$\mathrm{Z}$ tego powodu, zdaniem medyka, najbardziej zagrożone są kobiety, zwłaszcza brzemienne: A ta jest przyczyna, dlaczego niewiasty często powietrze morowe zalata, iz maja ciała pelne zlych wilgości, a zwłaszcza miedzy niewiastami najwięcej brzemienne powietrzu podlegty dla zadzierżenia miesięcznych upławow, krwawej choroby albo zwyktej białym glowom (12r-12v). W tej opinii kryje się oparte na wiedzy starożytnej przekonanie (tzw. teoria humoralna), że główną rolę w organizmie człowieka odgrywają cztery płyny ustrojowe, a zaburzenie równowagi między nimi uważano za źródło choroby. Umiastowski przekonuje więc, że konieczne jest pozbycie się tej jadowitej materyji wilgości ztych $(75 \mathrm{v})$, gdyż jak pisze: czego się dotknie, psuje $i$ we złe obraca $(75 \mathrm{v})$. Leksem ten zazwyczaj pojawia się w otoczeniu licznych pejoratywnie nacechowanych określeń: wilgości zte, jadowite, morowe prędkie sa do zamorodowania $(77 \mathrm{v})$.

Przekonanie o tym, że zakażenie wnikało do organizmu człowieka w trakcie oddychania tłumaczyć miało, dlaczego to właśnie ludzie prości najczęściej byli narażeni na zachorowanie: ktorzy wiele pracuja, gdyż często musza oddychać, łacno też powietrzem bywaja zarażeni, czego studzy ludzie prości doznawaja na sobie $(12 \mathrm{v})$. Rozprzestrzenianiu się choroby sprzyjać miały także złe warunki mieszkaniowe i brak higieny: przednia jest powietrza morowego żagiew lud pospolity i ubodzy, ktorzy i dla ścisłego mieszkania i dla złego zycia, najwięcej ze wszystkich bywaja zapowietrzeni i najwięcej ze wszystkich powietrze morowe rozszerzaja i roznosza (42r), Bo im najwiętsza w ktorym 
mieście wielkość ludzi, a mieszkania ciasne, tym tez najwiętsze morowe powietrze na onym mieścu panuje (44r). Umiastowski zauważa, że miasta dla wiatru grubego i zawartego od zapowietrzonych i zmartych z wilgości zepsowanego bardziej sq zapowietrzone, więcej niebezpieczne, a wsi daleko bezpieczneiejsze sa (42r), gdyż w mieścach albo w sklepach zamknionych pleśni petno z pary po ścianach, po stropie: tymże sposobem i pary powietrzne w mieścach zamknionych moga być (16v). Odpowiedzialne za przenoszenie zatrutego powietrza mogły być również wiatry wiejące $\mathrm{z}$ południa: wiatry z południa gorsze $i$ niezdrowsze (49r), z stron poludniowych na zachod powietrze morowe idzie (41r). Na stan zdrowia mogła też w znacznym stopniu wpływać kondycja psychiczna człowieka i jego system nerwowy. Według szesnastowiecznego autora lęk przed śmiercią i uporczywe myślenie o zagrożeniu, spowodowanym morowym powietrzem znacznie zwiększało prawdopodobieństwo zakażenia: Bojaźń powietrza morowego łacno do powietrza przywodzi, bojaźliwi czasem od samej bojaźni umieraja, nie tylko od powietrza $(58 \mathrm{v})$.

\section{WNIOSKI}

Ukazany $\mathrm{w}$ traktacie obraz choroby, zwanej morowym powietrzem, odzwierciedla z jednej strony dawny sposób postrzegania choroby, zgodny ze stanem ówczesnej wiedzy medycznej, ukształtowanej przez starożytne i średniowieczne autorytety medyczne, $\mathrm{z}$ drugiej zaś odsłania zakorzenione $\mathrm{w}$ języku potoczne myślenie o chorobie jako niechcianym, niebezpiecznym, groźnym, budzącym lęk przybyszu. Wzgląd na adresata poradnika, którym był prosty, niewykształcony odbiorca, spowodował konieczność odwoływania się w opisie naukowym do świata pozanaukowego, zewnętrznego, znanego czytelnikowi oraz sprawił, że niemożliwe było wyrwanie się z potocznych sposobów porządkowania pojęć i potocznej perspektywy interpretacyjnej. Tym trzeba tłumaczyć fakt, że wiele z wynotowanych określeń ma charakter językowo-kulturowej kreacji, w której kryje się ocena i określony sposób wartościowania choroby. Analiza językowa nazw, ich etymologii oraz łączliwości leksykalnej pozwoliła odsłonić kryjące się w nich najbardziej istotne dla człowieka informacje związane ze sposobem przenoszenia się morowego powietrza oraz o skutkach, jakie ono wywołuje: to choroba, która przychodziła znienacka, wraz z powietrzem, szybko i gwałtownie się rozprzestrzeniająca, masowo doprowadzająca do śmierci. Wiele spośród wynotowanych określeń odsłania typowy dla potocznego myślenia proces „oswajania” choroby przez jej uczłowieczenie. Umiastowski stosuje 
zabiegi związane z personifikacją (także animizacją) zarazy, szczególnie często sięga po wartościujące epitety (także w formie superlatywnych przymiotników) o ujemnym nacechowaniu, które umieszcza w postaci wielowyrazowych szeregowych zestawień, wywołując tym samym efekt kumulacji danej cechy, będącej atrybutem choroby. Również stosowane przez Umiastowskiego wielowyrazowe nominacje leksemów sygnalizujących określone treści było zabiegiem, w którym kryło się wartościowanie. Negatywne konotacje związane z chorobą i jej objawami ujawniały również stosowane przez medyka konstrukcje porównawcze o emocjonalnym zabarwieniu, których celem było oddziaływanie na sferę uczuciową odbiorcy i wzmocnienia w nim przekonania o szczególnej, ponadwymiarowej uciążliwości objawów wywołanych morowym powietrzem.

\section{WYKAZ SKRÓTÓW}

SPXVI Stownik polszczyzny XVI wieku, red. Maria Renata Mayenowa i in., t. 1-38, Zakład Narodowy im. Ossolińskich, Instytut Badań Literackich PAN, 1966- 2020.

SEBor Boryś, Wiesław. Słownik etymologiczny języka polskiego, Wydawnictwo Literackie, 2005.

Sstp Stownik staropolski, red. S. Urbańczyk, t. 1-11, Zakład Narodowy im. Ossolińskich, Wydawnictwo Polskiej Akademii Nauk, Wrocław - Warszawa - Kraków - Gdańsk - Łódź, 1952-2002.

SW Słownik języka polskiego, t. 1-8, red. Jan Karłowicz, Adam Kryński, Władysław Niedźwiedzki, Warszawa, 1900-1927.

SWil Stownik języka polskiego, t. 1-2, oprac. Aleksander Zdanowicz i in., Wilno, 1861.

\section{BIBLIOGRAFIA PODMIOTOWA}

Umiastowski, Piotr. Nauka o morowym powietrzu na czwory księgi rozłożona, Kraków, Drukarnia Andrzeja Piotrkowczyka, 1591. Sygnatura oryginału: XVI.Qu.2143; dostęp online: dbc.wroc.pl/dlibra/ publication/12212/edition/10754/content?\&action=ChangeMetaLangAction\&lang=pl

\section{BIBLIOGRAFIA PRZEDMIOTOWA}

Bartmiński, Jerzy. „Punkt widzenia, perspektywa, językowy obraz świata”. Językowy obraz świata, red. Jerzy Bartmiński, Uniwersytet Marii Curie-Skłodowskiej, 1999, ss. 103-120.

Biniewicz, Jerzy. „Początki polskiego języka nauk ścisłych (XVI-XVIII wiek)”. Studia historycznojęzykowe. Prace Językoznawcze, t. 24, 1996, ss. 62-70.

Biniewicz, Jerzy. Kształtowanie się polskiego języka nauk matematyczno-przyrodniczych. Wydawnictwo Uniwersytetu Opolskiego, 2002.

Biniewicz, Jerzy. „Początki polskiego stylu naukowego - między teorią naukową a praktyką gospodarczą". Stylistyka, t. 24, 2015, ss. 283-297. 
Borek, Piotr. „Staropolskie teksty literackie jako źródła do dziejów epidemii (rekonesans)”. Epidemie w dziejach Europy, red. Krzysztof Polek, Łukasz Tomasz Sroka, Wydawnictwo Naukowe UP, 2016, ss. 201-219.

Chojnacka-Kuraś, Marta. „Kiedy walka staje się podróżą. O przeobrażeniach metafor opisujących doświadczenie chorowania z uwzględnieniem typu i fazy choroby”. Prace Filologiczne, t. 73, 2019, ss. 33-48.

Giedroyć, Franciszek. Mór w Polsce w wiekach ubiegłych. Zarys historyczny. Druk L. Szkaradzińskiego i S-ki, 1899.

Jankowiak, Lucyna Agnieszka. „Terminologia medyczna w dziele Stefana Falimirza na tle polszczyzny XVI wieku (Próba rekonesansu)". Slavia Occidentalis, t. 57, 2000, ss. 37-50.

Jankowiak, Lucyna Agnieszka. „Nazwy chorób w polszczyźnie XVI wieku (Próba ogólnej charakterystyki)”. Slavia Occidentalis, t. 58, 2001, ss. 9-18.

Jankowiak, Lucyna Agnieszka. Stownictwo medyczne Stefana Falimirza, t. 1: Poczatki polskiej renesansowej terminologii medycznej. Slawistyczny Ośrodek Wydawniczy, 2005.

Jankowiak, Lucyna Agnieszka. Stownictwo medyczne Stefana Falimirza, t. 2: Stownik. Slawistyczny Ośrodek Wydawniczy, 2006.

Jankowiak, Lucyna Agnieszka. „Z dziejów terminologii medycznej. Słownictwo medyczne wieku XVI wobec XVII w. oraz pierwszej połowy XVIII w.”. Studia z Filologii Polskiej i Słowiańskiej, t. 44,2009 , ss. 61-83.

Jankowiak, Lucyna Agnieszka. „Zapożyczenia w XVI-wiecznym słownictwie medycznym i ich dzisiejsze losy (na materiale zielnika Stefana Falimirza)". Linguistica Copernicana, t. 4, nr 2, 2010, ss. 201-213.

Kamper-Warejko, Joanna. „Poradnik Piotra Krescencjusza jako tekst użytkowy”. Studia z Filologii Polskiej i Stowiańskiej, t. 46 SOW, 2011, ss. 43-56.

Karpiński, Andrzej. W walce z niewidzialnym wrogiem. Neriton, Instytut Historii PAN, 2000.

Kracik, Jan. Pokonać czarna śmierć. Staropolskie postawy wobec zarazy. Wydawnictwo M, 1991.

Kuran, Michał. „Źródła barokowej wiedzy medycznej i ich autorytetu oraz zaufanie wobec leczących w świetle wybranych tekstów z pierwszej połowy XVII w. o zwalczaniu dżumy”. Analecta. Studia i Materiaty z Dziejów Nauki, z. 2, 2020, ss. 61-81.

Kuryłowicz, Beata. „Terminologia medyczna w Nowym Dykcjonarzu Michała Abrahama Troca na tle źródeł z XVI i XVII wieku”. Poradnik Językowy, z. 5-6, 2020, ss. 76-87.

Marczewska, Marzena. Ja cię zamawiam, ja cię wypędzam.... Choroba. Studium językowo-kulturowe. Wydawnictwo UJK, 2012.

Marczewska, Marzena. „Wyobrażenia choroby utrwalone w języku polskim”. Gawędy o kulturach, t. 1, red. Joanna Szadura, Polihymnia, 2014, ss. 87-95.

Migdał, Jolanta. „O nazywaniu człowieczych chorób - uwagi o słownictwie Glaberowych Gadek”. Synchroniczne i diachroniczne aspekty badań polszczyzny, t. 8, red. Mirosława Białoskórska, Leonarda Mariak, Wydawnictwo Naukowe Uniwersytetu Szczecińskiego, 2002, ss. 147-157.

Piela, Agnieszka. „W cieniu koronawirusa... Historycznie o zarazie i zarazkach”. Poradnik Językowy, z. 6-7, 2020, ss. 97-105.

Raszewska-Żurek, Beata. „Metaforyzacja antywartości w dawnej polszczyźnie - konwencjonalność ujęć na przykładzie metafory ANTYWARTOŚĆ TO CHOROBA”. Polonica, t. 38, 2018, ss. 1-19. 
Siekierska, Krystyna. „Uwagi o języku i stylu dzieł naukowych XVII wieku (botanika, medycyna, geometria)”. Odmiany polszczyzny XVII wieku, red. Halina Wiśniewska, Czesław Kosyl, Wydawnictwo UMCS, 1992, ss. 107-114.

Siekierska, Krystyna. „Z dziejów kształtowania się języka nauki polskiej. Funkcje porównań w średniopolskich źródłach medycznych”. Polonica, t. 9, 1983, ss. 211-229.

Stec, Magdalena. „Konceptualizacja pojęcia choroba w polszczyźnie”. Poradnik Językowy, nr 1, 2007, ss. 20-32.

Steczko, Iwona. „Przymiot albo dworska niemoc i jej synonimiczne miana w polszczyźnie XV i XVI wieku”. Epidemie w dziejach Europy, red. Krzysztof Polek, Łukasz Tomasz Sroka, Wydawnictwo Naukowe UP, 2016, ss. 156-168.

Umińska-Tytoń, Elżbieta. „Potoczne nazwy chorób i dolegliwości w księgach parafialnych Mileszek z XIII wieku”. Rozprawy Komisji Językowej ŁTN, t. 36, 1990, ss. 205-218.

Umińska-Tytoń, Elżbieta. Potoczne określenia chorób i dolegliwości w księgach parafialnych Mileszek z XVIII wieku (cz. II). Rozprawy Komisji Językowej ŁTN, t. 36, 1990, ss. 199-205.

\author{
OBRAZ ZARAZY W ŚWIETLE TRAKTATU MEDYCZNEGO \\ PIOTRA UMIASTOWSKIEGO PT. NAUKA O MOROWYM POWIETRZU \\ NA CZWORY KSIĘGI PRZEŁOŻONA (1591)
}

Streszczenie

Celem artykułu jest ukazanie obrazu zarazy wykreowanego przez Piotra Umiastowskiego w traktacie medycznym pt. Nauka o morowym powietrzu na czwory księgi przełożona (1591). W tym celu omawia się synonimię związaną z nazwami choroby, cechy i atrybuty zarazy oraz towarzyszących jej objawów, genezę epidemii, a także ukazuje metaforyczne sposoby postrzegania choroby. Analizy zmierzają do odtworzenia dawnego sposobu konceptualizowania choroby, który warunkowany jest z jednej strony ówczesnym poziomem sztuki medycznej, z drugiej zaś utrwalonym w języku potocznym wyobrażeniem choroby. W toku analiz uwagę zwraca się także na wybrane zabiegi językowe, kształtujące obraz choroby, zwłaszcza udział leksyki wartościującej oraz wybrane środki stylistyczne, związane z funkcją artystyczną (porównania, przenośnie, epitety).

Slowa kluczowe: Piotr Umiastowski; Nauka o morowym powietrzu; traktat medyczny; obraz choroby w polszczyźnie XVI wieku; słownictwo medyczne XVI wieku; leksyka wartościująca.

\title{
THE PLAGUE IN PIOTR UMIASTOWSKI'S MEDICAL TREATISE NAUKA O MOROWYM POWIETRZU NA CZWORY KSIĘGI PRZELOŻONA (1591)
}

\section{S u m m ary}

This article aims to show the picture of the plague as created by Piotr Umiastowski in his medical treatise entitled Nauka o morowym powietrzu na czwory księgi przetożona from 1591. It discusses the synonymy connected with the names of illnesses, the features of the plague and its symptoms, the origins of the epidemic, as well as the ways illness can be perceived in metaphorical terms. The analyses are intended to show the past methods of conceptualising an illness, which was, on the one hand, 
determined by the medical science of sixteenth century, and, on the other, by the idea of illness as preserved in colloquial language. The research also points to chosen linguistic devices which form the image of an illness, in particular the evaluative lexicon and given stylistic devices that perform the artistic functions of language (comparison, metaphor, epithets).

Keywords: Piotr Umiastowski; Nauka o morowym powietrzu; medical treatise; disease description in 16th-century Polish; medical terminology in 16th century; evaluative lexicon. 